\title{
Infraorbital Neuralgia Secundary to a Retention Mucous Cyst in Maxillary Sinus: A Case Report
}

\author{
Thiago Messias Zago* \\ Departament of Otorhinolaryngology, Hospital Sao Francisco Mogi, Brazil
}

Submission: February 23, 2018; Published: March 12, 2018

*Corresponding author: Thiago Messias Zago, Departament of Otorhinolaryngology, Head and Neck surgery, Hospital Sao Francisco Mogi, Guacu, Brazil, Email: thiagomzago@hotmail.com

\section{Introduction}

The infraorbital nerve is a branch of the maxillary nerve which emerges in the infraorbital foramen in the roof of the maxilary sinus [1]. The infraorbital neuralgia is a king of trigeminal neuralgia, a patology more common in elder people and is unnilateral in $95 \%$ of the cases [2]. The charachetiscs of trigeminal neuralgia include sudden, severe, periodic, stabbing, lancinating, lightining-like and shock-like pain attacks in the territory of the 2 th or 3 th portion of the trigeminal nerve [3]. The purpose of this article is describe a case of infraorbital neuralgia casued by an uncommum sequelae of acute rhinossinusitis: a retention mucous cyst.

\section{Case report}

Male, 62 years old with a paroxistic and intense pain in the region of the zigomatic arch desencadeated by chew that lasted minuts and was followed by a moderate pain in the same region for some hours. All the attacks were associated with the sensantions of ipsilateral nasal obstruction. This patient had no comorbidities and no chronic nasal symptons. RMI was normal, nasoendoscopy was normal and the head and sinuses CT showed a retention mucous cyst in the area of the infraorbital foramen. These exams showed no other anormalities. Because of the risk of lesion of the infraorbital nerve in a surgery to remove the retention mucous cyst it was decided to initiate amytriptiline ina dose of $25 \mathrm{mg}$ dially. The patient after some days referred total recovery of the pain, with high impact in his quality of life.

\section{Discussion}

The trigeminal neuralgia can be divided in primary or idiopathic, when no cause is identified and in secondary when a cause is identified in the central nervous system: tumor, infartion, multiple sclerosis or trauma [4]. According to the symptomatic aspect, the trigeminal neuralgia can be divided in "typical", when the pain is paxorismal and "atypical", when the paroxismal pains is associated with constant pain, as the patient descrbied in the case [5]. The pathophysiology of idiopathic of TN occurs due to the specific abnormalities of the trigeminal nerve in the trigeminal root or ganglion.The pathophysiological characteristics of classic or idiopathic TN are identified with the pressure of the trigeminal nerve root by a vein at or nearby the root passage zone. An artery crossing the nerve can provoke further displacement, which can lead to damage and injury of the trigeminal nerve [6].

The diagnostic is essentially clinical, but some image investigation is necessary. It is recommended that a Computed Tomography and a Magnetic Ressonace be performed to exclude seconday causes [7]. Several treatments have been described for TN: the first line are anticonvulsivants as carbamazepine but other drugs has positive effects like gabapentin, baclofen, lamotrigin and amytriptiline. More recently, non pharmacological treatments have been described as ultrasoundguided infraorbital nerve block with combination of steroid and local anesthetic [8] and Pulsed Radiofrequency Treatment Guided by Computed Tomography for Refractory Neuralgia of Infraorbital Nerve [9].

\section{References}

1. López Mesonero L, Pedraza Hueso MI, Herrero Velázquez S, Guerrero Peral AL (2014) Infraorbital neuralgia a diagnostic possibility in patients with zygomatic arch pain. Neurologia 29(6): 381-382.

2. MC Ichida, L Alvarenga Da Silva, MJ Teixeira, JTT De Siqueira, RDT De Siqueira (2015) Functional and sensory evaluation of patients with idiopathic trigeminal neuralgia: Comparison with controls. Clinical Neurology and Neurosurgery 130: 114-121.

3. P Rasmussen (1990) Facial pain II A prospective survey of 1052 patients with a view of: Character of the attacks onset course and character of pain. Acta Neurochirurgica 107(3-4): 121-128.

4. Beigi B, Beigi M, Niyadurupola N, Saldana M, El Hindy N (2017) Infraorbital Nerve Decompression for Infraorbital Neuralgia Causalgia following Blowout Orbital Fractures A Case Series. Craniomaxillofac Trauma Reconstr 10(1): 22-28.

5. K Toda (2007) Etiology of Trigeminal Neuralgia Oral Science International 4 (1): 10-18.

6. Khan M, Nishi SE, Hassan SN, Islam MA, Gan SH (2017) Trigeminal Neuralgia Glossopharyngeal Neuralgia and Myofascial Pain Dysfunction Syndrome An Update. Pain Res Manag 2017: 7438326. 
7. Yadav YR, Nishtha Y, Sonjjay P, Vijay P, Shailendra R, et al. (2017) Trigeminal Neuralgia. Asian J Neurosurg 12(4): 585-597.

8. Cok OY, Deniz S, Eker HE, Oguzkurt L, Aribogan A (2017) Management of isolated infraorbital neuralgia by ultrasound-guided infraorbital nerve block with combination of steroid and local anesthetic. J Clin Anesth 37: 146-148.

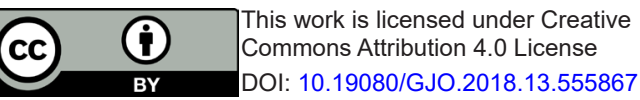

9. Luo F, Lu J, Shen Y, Meng L, Wang T, et al. (2015) Effectiveness and Safety of Pulsed Radiofrequency Treatment Guided by Computed Tomography for Refractory Neuralgia of Infraorbital Nerve A Pilot Study. Pain Physician 18(5): 795-804.

\section{Your next submission with Juniper Publishers} will reach you the below assets

- Quality Editorial service

- Swift Peer Review

- Reprints availability

- E-prints Service

- Manuscript Podcast for convenient understanding

- Global attainment for your research

- Manuscript accessibility in different formats

( Pdf, E-pub, Full Text, Audio)

- Unceasing customer service

Track the below URL for one-step submission https://juniperpublishers.com/online-submission.php 